\title{
Characterization of crown node elevation in Panicoid grasses
}

\author{
C.R. TISCHLER AND P.W. VOIGT
}

\begin{abstract}
Authors are plant physiologist and supervisory research geneticist, USDA-ARS, 808 East Blackland Road, Temple, Tex. 76502 .
\end{abstract}

\begin{abstract}
In Panicoid grasses, elevation of the crown node above the soil surface caused by excessive subcoleoptile internode elongation is detrimental to seedling establishment. We describe a technique to screen grass seedlings for excessive crown node elevation. Seed of 11 perennial grass cultivars were germinated and grown in a plywood box $1.2 \times 1.2 \times 1.2 \mathrm{~m}$ at an irradiance of $1.5 \mu \mathrm{mol} \mathrm{m}^{-2} \mathrm{sec}^{-1} \mathrm{at}$ $30^{\circ}$ C. A subset of 8 grasses were grown similarly but at an irradiance of $0.75 \mu \mathrm{mol} \mathrm{m}^{-2} \mathrm{sec}^{-1}$. Elevation of crown nodes above the growth media and shoot length (from crown node to leaf tip) were measured 7 days after planting. The crown nodes of 4 Eragrostis species were not elevated above the soil surface, while other species had mean crown node elevations of $1 \mathrm{~cm}$ or more. Relative ranking of crown node elevation was similar for a specles within each light level, but response to change in light intensity was not consistent across species. Sideoats grama (Bouteloua curtipendula (Michx.) Torr.), blue grama (Bouteloua gracilis (H.B.K. Lag. ex Steud.)), and kleingrass (Panicum coloratum $L$.) exhibited significant crown node elevation in this system. Estimates of genetic variation based on comparison of apomictic and sexual grasses within this group suggest that substantial genetic variation exists for excessive subcoleoptile internode elongation and that progress by selection for lower crown node placement should be possible in most of the grasses studied. This system allows characterization of grasses for extent of crown node elevation and is being used in a recurrent selection protocol to select for lower crown node placement.
\end{abstract}

Key Words: adventitious roots, crown node, phytochrome, seedling establishment

In Panicoid grasses, the subcoleoptile internode of the developing seedling elongates to elevate the coleoptile to the soil surface (Hyder et al. 1971). Elongation of the subcoleoptile internode stops after the tip of the coleoptile perceives red light. The classical work of van Overbeek (1936) indicated that illumination of the coleoptile stopped auxin production, which caused tissues below the coleoptile tip to stop elongating. Ideally, the perception of the light stimulus, the interruption of auxin supply, and the cessation of growth all occur before the crown node (located between the coleoptile and the subcoleoptile internode) is elevated above the soil surface.

In Panicoid grasses the crown node is the point of origin of nodal, adventitious roots. Establishment of a grass seedling is dependent on the development of adventitious roots; elevation of the crown node above the soil surface can prevent adventitious root initiation and impede growth. This argument was first advanced by Olmsted (1941), who indicated that establishment of sideoats grama (Bouteloua curtipendula (Michx.) Torr.) was

Contribution of the USDA-ARS.

Manuscript accepted 1 Mar. 1993. limited by excessive crown node elevation. Hyder (1971) and Tischler et al. (1987) made similar observations for blue grama (Bouteloua gracilis (H.B.K. Lag. ex Steud.)) and kleingrass (Panicum coloratum L.), respectively. A seedling with a crown node elevated above the soil surface and no adventitious roots is attached to the soil only by the delicate subcoleoptile internode, which is easily broken, leading to death of the seedling.

Several factors, acting either independently or in concert, are responsible for excessive crown node elevation in the field. Overcast conditions or emergence at night would reduce the amount of red light received by the seedling and could delay the blockage of subcoleoptile internode elongation, thus allowing elevation of the crown node above the soil surface. Also, the presence of tall vegetation has been shown to enrich the far red:red light ratio at the soil surface (Kasperbauer 1987, Yahalom et al. 1987). Species differences in response to the quality and quantity of incident light could be responsible for the magnitude of crown node elevation observed in some grasses, but this possibility has never been investigated. We propose that the excessive crown node elevation sometimes observed in the field is caused by a high red light saturation requirement of the receptor controlling subcoleoptile internode elongation. Our objectives were to devise a protocol to evaluate grass species for potential excessive crown node elevation (above the soil surface) and to characterize variability within cultivars of those species.

\section{Materials and Methods}

Two boxes measuring $1.2 \times 1.2 \times 1.2 \mathrm{~m}$ were constructed from plywood. One side of each box was hinged to allow access. Five 6-watt incandescent light bulbs (Sylvania \#16933-0, approx. 2800 ${ }^{\circ} \mathbf{K}$, having maximum energy output at approximately 1,000 nanometers) were installed on the ceiling of the boxes; 1 bulb was inset $0.12 \mathrm{~m}$ from each corner, and 1 bulb was placed in the center. Measurements with a Licor Model LI-185' light meter equipped with a quantum sensor indicator that this arrangement provided a uniformly lighted plant growth area of approximately $0.25 \mathrm{~m}^{2}$ in the center of the box. We selected a light source relatively rich in far-red light to simulate conditions of light competition. Although other light sources and configurations would probably be suitable, the materials used are readily available at reasonable cost, and preliminary experiments indicated that light level was appropriate to allow discrimination in response both within and between species.

To make environmental conditions as uniform as possible, thus minimizing nongenetic (i.e., environmental) variation, and because we were interested only in the physiological response of the crown node to a given irradiance, continuous temperature and light conditions were used. Temperature control was achieved by circulating water from a water bath through heater hoses to an automobile heater core inside the boxes. The temperature control system allowed maintenance of temperature at $30.0 \pm 1^{\circ} \mathrm{C}$, an ideal 
Table 1. Crown node elevation and length of shoot at $1.5 \mu \mathrm{mol} \mathrm{m}-2 \mathrm{sec}^{-1}$ irradiance.

\begin{tabular}{|c|c|c|c|c|c|c|c|c|c|}
\hline \multirow[b]{2}{*}{ Grass } & \multirow[b]{2}{*}{ MOR $^{1}$} & \multicolumn{4}{|c|}{ Node Elevation } & \multicolumn{4}{|c|}{ Shoot Length } \\
\hline & & Min & $\operatorname{Max}$ & Mean & SD & Min & $\operatorname{Max}$ & Mean & SD \\
\hline & & & & & & & & & \\
\hline Boer love² & $\mathbf{A}$ & 0.0 & 0.0 & $0.00^{3}$ & 0.000 & 1.3 & 3.0 & $2.15^{3}$ & 0.365 \\
\hline Wilman love & $\mathbf{S}$ & 0.0 & 0.1 & $0.01 \mathrm{e}$ & $0.035 \mathrm{NS}$ & 1.3 & 2.6 & $2.05 \mathrm{de}$ & $0.337 \mathrm{NS}$ \\
\hline Atherstone love & $\mathbf{A}$ & 0.0 & 0.1 & $0.05 \mathrm{de}$ & 0.031 & 0.4 & 1.1 & $0.74 f$ & 0.192 \\
\hline Sand love & $\mathbf{S}$ & 0.0 & 0.3 & $0.08 \mathrm{de}$ & $0.107^{* *}$ & 1.0 & 3.5 & $2.15 \mathrm{cde}$ & $0.501^{*}$ \\
\hline Blue grama, Hachita & $\mathbf{S}$ & 0.0 & 0.5 & $0.14 c d$ & $0.132^{* *}$ & 1,1 & 4.0 & $2.55 \mathrm{~cd}$ & $0.686^{* *}$ \\
\hline Blue grama, Alma & $\mathbf{S}$ & 0.0 & 0.5 & $0.22 c$ & $0.147^{* *}$ & 0.9 & 4.3 & $2.79 c$ & $0.896^{* *}$ \\
\hline Big bluestem & $\mathbf{S}$ & 0.0 & 1.1 & $0.26 c$ & $0.325^{* *}$ & 1.4 & 6.5 & $4.02 \mathrm{~b}$ & $1.158^{* *}$ \\
\hline Switch & $\mathbf{S}$ & 0.1 & 2.3 & $0.71 \mathrm{~b}$ & $0.395^{* * *}$ & 2.2 & 5.0 & $3.75 \mathrm{~b}$ & $0.755^{* *}$ \\
\hline Green sprangletop & $\overline{\mathbf{S}}$ & 0.5 & 1.0 & $0.78 b$ & $0.110^{* * *}$ & 1.3 & 3.5 & $2.40 \mathrm{cde}$ & $0.545^{* *}$ \\
\hline Klein & $\mathbf{S}$ & 0.1 & 1.5 & $0.79 b$ & $0.401^{* * *}$ & 1.2 & 3.1 & $1.94 \mathrm{e}$ & $0.427 \mathrm{NS}$ \\
\hline Sideoats grama & S & 0.0 & 1.6 & $0.93 \mathrm{~b}$ & $0.468^{* *}$ & 2.0 & 7.0 & $4.47 \mathrm{~b}$ & $1.325 * *$ \\
\hline Sorghum & S & 0.3 & 2.0 & $1.25 \mathrm{a}$ & $0.489^{* *}$ & 3.0 & 8.0 & $5.62 \mathrm{a}$ & $1.246 * *$ \\
\hline
\end{tabular}

${ }^{1}$ Mode of reproduction, $A=$ apomictic and $S=$ sexual.

${ }^{2}$ Boer lovegrass excluded from node elevation statistical analyses because of the absence of any variation among plants.

${ }^{3}$ Values within columns followed by the same letter are not significantly different at the 0.05 probability level.

$*, *$ Standard deviations of sexual greater than those of the apomictic grasses at the 0.05 or 0.01 probability level, respectively, by ANOVA single degree of freedom contrast.

temperature for most warm-season grasses. In 1 box, $50 \%$ shade cloth covers were placed over each of the bulbs. Irradiance at plant level ( $8 \mathrm{~cm}$ above a rack, $0.5 \mathrm{~m}$ below the level of the lights) was approximately $1.5 \mu \mathrm{mol} \mathrm{m} \mathrm{sec}^{-1}$ in the box without shade cloth ("low light") and $0.75 \mu \mathrm{mol} \mathrm{m}^{-2} \mathrm{sec}^{-1}$ in the box with shade cloth ("very low light").

This type of experiment cannot be performed under field or day/night conditions because light is a variable, and any differences observed may be caused by timing, duration, or intensity of light treatment rather than by the inherent genetic potential of the light-sensing system. Likewise, we recognize that the light levels employed were well below the light compensation point of the grasses, but our objective was to maximize any differential response of crown node placement of species and individuals to light, not to optimize seedling growth rate or provide "normal" growing conditions.

Eleven perennial grass cultivers (representing 10 species) were studied. Seed of 'Hachita' and 'Alma' blue grama, 'Haskell' sideoats grama, 'Trailblazer' switchgrass (Panicum virgatum L.), 'Kaw' big bluestem (Andropogon gerardi Vitman), 'A-84' boer lovegrass (Eragrostis curvula var. conferta Nees), 'Cochise' atherstone lovegrass (Eragrostis lehmanniana Nees $\times E$. tricophera Coss and Dur.), 'Mason' sand lovegrass (Eragrostis trichoides (Nutt.) Wood), and 'Van Horn' green sprangletop (Leptochloa dubia (H.B.K.) Nees) were obtained from SCS Plant Materials Centers. Seed of 'Selection 75' kleingrass and 'Palar' Wilman lovegrass (Eragrostis superba Peyr.) were produced at Temple, and seed of sorghum (Sorghum bicolor) hybrid 264YG were obtained from Triumph'Seed Company. Mode of reproduction of Cochise atherstone lovegrass and 'A-84' boer lovegrass is by apomixis; the other grasses reproduce sexually.

Seeds were planted at a depth of $0.5 \mathrm{~cm}$ in 9-cm square plastic pots in commercial peat-vermiculite potting mix. Each pot contained 3 rows of seed, each row consisting of a different species, with species assigned in a random design. Twenty seed were planted per row. Pots were watered, allowed to drain, and placed in the light box. After 7 days, 10 consecutive seedlings from each row were sampled. Occasional abberant plants (albinos, seedlings with twisted leaves, etc.) were not measured. The elevation of the crown node above the surface of the rooting media and the distance from the crown node to the tip of the first leaf (shoot length) were measured. Measurements were made using a plastic ruler and magnifying desk lamp, because the crown nodes of some species

${ }^{1}$ Mention of a proprietary product does not constitute an endorsement or recommendation for its use by USDA. could not be easily seen without magnification.

In the first experiment, all grasses were studied at the low light level. Subsequently, 8 of the 12 grass species were evaluated at the very low light level, employing the box equipped with shade cloth. Both experiments were repeated 3 times. Each separate experiment was analyzed as a randomized complete block (RCB) design with subsampling. Also, the standard deviations (SD) of the subsamples were calculated to obtain an estimate of within cultivar variability, and were analyzed as random complete block design. All analyses assumed a fixed model. Because of a relationship between grass species means and their variances, data were square root transformed prior to statistical analysis (Steel and Torrie 1980). Residual plots indicated that the transformation alleviated variance heterogeneity (Fernandez 1992). Results presented are in the original scale, but statistics are based on the transformed data. Entry means were compared using Duncan's new multiple range test. Additionally, the entries source of variance, in the standard deviation analysis, was subdivided into apomict vs sexual, among apomicts, and among sexual components. Finally, as part of the analysis of variance, to determine if genetic variation existed for both crown node elevation and shoot length, single degree of freedom contrasts were used to compare the standard deviations of the apomictic grass(es) with each of the sexual grasses. This analysis assumes that variation within the genetically uniform apomicts is an estimate of environmental variation while that within the sexual entries consists of genetic and environmental components.

To examine the effect of light level and the grass by light level interaction, a pooled error term, checked for homogeneity, was used as part of a combined analysis of variance (Cochran and Cox 1957). We recognize that light level and light box were confounded. However, the 2 boxes were identical in construction, and mean temperature and temperature variation were identical in both boxes.

\section{Results}

Crown node height and shoot length of seedlings grown in the low light $\left(1.5 \mu \mathrm{mol} \mathrm{m} \mathrm{m}^{-2} \mathrm{sec}^{-1}\right)$ box varied widely among species (Table 1). The 4 lovegrasses exhibited little or no excessive crown node elevation. Moderate to extensive crown node elevation was observed for the remainder of the grasses. Standard deviations were significantly larger on average for sexual than for apomictic species, but differences also existed among sexual species. All sexually reproducing grasses except Wilman lovegrass were more variable than the apomictic grasses. Blue grama had very little variation, in contrast with a high level of variation for kleingrass 
Table 2. Crown node elevation and length of shoot at $0.75 \mu \mathrm{mol} \mathrm{m} /{ }^{2} / \mathrm{sec}$ irradiance.

\begin{tabular}{|c|c|c|c|c|c|c|c|c|c|}
\hline \multirow[b]{2}{*}{ Grass } & \multirow[b]{2}{*}{ MOR $^{1}$} & \multicolumn{4}{|c|}{ Node Elevation } & \multicolumn{4}{|c|}{ Shoot Length } \\
\hline & & Min & $\operatorname{Max}$ & Mean & SD & Min & Max & Mean & SD \\
\hline & & & 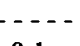 & & - & & & & \\
\hline Sand love & $\mathbf{S}$ & 0.0 & 0.1 & $0.02 \mathrm{~d}^{2}$ & $0.045 \mathrm{NS}$ & 1.2 & 2.6 & $2.00 \mathrm{c}$ & $0.520^{* *}$ \\
\hline Wilman love & $\mathbf{S}$ & 0.0 & 0.3 & $0.03 \mathrm{~d}$ & $0.077 \mathrm{NS}$ & 1.2 & 3.1 & $2.29 \mathrm{bc}$ & $0.383^{*}$ \\
\hline Big bluestem & $\mathbf{S}$ & 0.0 & 0.6 & $0.13 \mathrm{c}$ & $0.189^{* *}$ & 2.0 & 5.1 & $3.44 a$ & $0.850^{* *}$ \\
\hline Atherstone love & A & 0.0 & 0.3 & $0.14 c$ & 0.069 & 0.6 & 1.9 & $1.03 \mathrm{~d}$ & $0.221-$ \\
\hline Blue grama, Alma & $\mathbf{S}$ & 0.0 & 0.6 & $0.32 b$ & $0.181^{* *}$ & 2.0 & 4.1 & $3.31 \mathrm{a}$ & $0.606^{* *}$ \\
\hline Green sprangletop & $\mathbf{S}$ & 0.0 & 0.9 & $0.55 \mathrm{a}$ & $0.210^{* *}$ & 0.9 & 3.1 & $2.12 \mathrm{c}$ & $0.478 * *$ \\
\hline Switch & $\mathbf{S}$ & 0.0 & 1.5 & $0.60 \mathrm{a}$ & $0.426^{* *}$ & 1.1 & 4.5 & $3.48 \mathrm{a}$ & $0.913^{* *}$ \\
\hline Klein & $S$ & 0.1 & 2.1 & $0.83 \mathrm{a}$ & $0.495^{* *}$ & 2.1 & 3.4 & $2.63 \mathrm{~b}$ & $0.420^{* *}$ \\
\hline
\end{tabular}

Mode of reproduction, $A=$ apomictic and $S=$ sexual.

2Values within columns followed by the same letter are not significantiy different at the 0.05 probability level.

*,* "Standard deviations of sexual greater than those of the apomictic grasses at the 0.05 or 0.01 probability level, respectively, by ANOVA single degree of freedom contrast.

and switchgrass. However, shoot length variation was low for kleingrass and Wilman lovegrass, but high for big bluestem, sideoats grama, and sorghum. The correlation between crown node elevation and shoot length was $0.62(P>0.05)$. However, the relationship was species-dependent. If only the grasses studied at very low light level were included, the correlation coefficient was reduced to 0.39 .

Relative crown node elevation of the grasses grown in the "very low light" box (Table 2) was similar to that at the low light level. Over all grasses, light level had no effect on mean or standard deviation of node elevation or shoot length. Interactions between light levels and grasses were significant for mean node elevation and shoot length and standard deviation of node elevation. Big bluestem and blue grama were the 2 grasses most responsible for differential performance between light levels. However, correlation coefficients between the 2 light levels for the characteristics studied were $\mathrm{r}=0.92,0.85,0.92$, and 0.90 (all $P>0.01$ ) for mean and standard deviation of node elevation and shoot length, respectively. Crown node elevation and shoot length were not related $(r=$ 0.30).

\section{Discussion}

Our observations are in agreement with the reported tendency for excessive crown node elevation in the field for sideoats grama, blue grama, and kleingrass. Because these grasses, and individual plants within each species, vary in response to low light levels, it is clear that individual plants must have different sensitivities of the light receptors in the crown node. The consistent behavior of the Eragrostis entries suggests no problem should be encountered with crown node elevation in the field for these species, and none has been reported in the literature. Although the marked crown node elevation of sorghum could be taken to indicate a problem could exist in this species, it must be remembered that sorghum is generally planted in a clean, prepared seedbed, where light level at the soil surface is optimal. Also, sorghum is usually planted more deeply than the other grasses studied and has a relatively long coleoptile, which helps to minimize crown node elevation (Tischler et al. 1987).

Of the grasses studied that are adapted to arid range sites, only green sprangletop has appreciable crown node elevation. This grass, a short-lived perennial, is sometimes used in mixtures because of better initial establishment than many other warmseason perennial grasses. If, as we believe, the described procedure predicts crown node elevation in the field, then green sprangletop must have other mechanisms that compensate for its slow response to light and are responsible for its establishment ability.

The lack of an obvious dose response of crown node elevation or shoot length to light suggests that the 2 light sensing organs involved in the respective growth responses (crown node and leaf) have similar dose responses to the light levels used in these experiments. Subcoleoptile internode elongation is controlled (via auxin supply from the coleoptile tip) by photoreceptive cells in the crown node, with the coleoptile merely acting as a fiber optic bundle (Parks and Poff 1986). Leaf emergence from the coleoptile is followed by senescence of this structure. Subsequent leaf elongation is controlled by a sensing system in the leaf itself (Kasperbauer 1987). Although less is known about the light sensing system in the leaf, control of leaf elongation is probably based on a phytochrome type receptor (Kasperbauer 1987).

The presence of significant genetic variation for both crown node elevation and for shoot length suggests that both characteristics should respond to selection in most of the sexually reproducing grasses studied. Although our estimates of genetic variation within grasses are not as robust as might be provided by other methods, and could be improved by inclusion of other apomictic species, they are valid assessments of the genetic variability present. Green sprangletop is at least partially self-fertilized (Hitchcock and Chase 1950), which is consistent with its being intermediate to low in standard deviation for both characteristics in both light levels. This supports our conclusions and the validity of the procedures used. Other grasses studied are normally cross-fertilized. Only the lovegrasses showed little potential for genetic improvement. This suggests the possibility of improving crown node placement in difficult to establish grasses such as blue grama and kleingrass.

Although shoot length in itself probably has no effect on crown node elevation, the variability observed may reflect seedling growth rate (seedling vigor). If this relationship were proven, shoot length could be used as a selection criterion concomitantly with selection for crown node placement. Either light level appeared effective for evaluating node elevation of most grasses studied, although the larger standard deviation for big bluestem at $1.5 \mu \mathrm{mol}$ $\mathrm{m}^{-2} \mathrm{~s}^{-1}$ suggests that selection under the low light would be more effective in identifying extreme genotypes of that grass than under very low light $\left(0.75 \mu \mathrm{mol} \mathrm{m} \mathrm{m}^{-2}\right)$.

We believe this system offers several advantages in selection for crown node placement. Continuous illumination negates any influence of time of day at emergence on crown node placement, as would be encountered in a diurnal light cycle system. Constant temperature eliminates temperature gradients within the potting mix in the plastic pots. The use of a nondestructive method, along with plastic pots and potting mix rather than petri dishes or similar devices is advantageous for use in a recurrent selection program for crown node elevation. After sampling, all unwanted seedlings may be destroyed. The desired seedlings are thus already rooted, and do not have to be replanted.

This system appears to be a useful way to study subcoleoptile 
Hoagland, D.R., and D.I. Arnon. 1950. A table of composition of two nutrient solutions. California Agr. Exp. Sta. Circ. 347. Berkeley.

Johnson, D.A., and M.D. Rumbaugh. 1981. Nodulation and acetylene reduction by certain rangeland legume species under field conditions. $J$. Range Manage. 34:178-181.

Lutwick, L.E., and A.D. Smith. 1977. Yield and composition of alfalfa and crested wheatgrass, grown singly and in mixture, as affected by $N$ and $P$ fertilizers. Can. J. Plant Sci. 57:1077-1083.

Mayland, H.F. 1986. Factors affecting yield and nutritional quality of crested wheatgrass, p. 216-266. In: K.L. Johnson (ed.), Crested wheatgrass: Its values, problems, and myths; Symp. Proc. Utah State Univ., Logan.

Nelson, D.A., and L.E. Sommers. 1973. Determination of total nitrogen in plant material. Agron. J. 65:109-112.

Porter, L.K., and W.A. ODean. 1977. Apparatus for preparing nitrogen from ammonium chloride for nitrogen-15 determination. Anal. Chem. 49:514-516.

Rumbaugh, M.D. 1982. Reseeding by eight alfalfa populations in a semiarid pasture. J. Range Manage. 35:84-86.

Rumbaugh, M.D., and M.W. Pedersen. 1979. Survival of alfalfa on five semiarid range seedlings. J. Range Manage. 32:48-51.

Ruschel, A.P., P.B. Vose, E. Matsui, R.L. Victoria, and S.M. Tsai Saito. 1982. Field evaluation of $\mathrm{N}_{2}$ fixation and $\mathrm{N}$-utilization by Phaseolus bean varieties determined by ${ }^{15} \mathrm{~N}$ isotope dilution. Plant Soil 65:397-407.
Schwendiman, J.L., and V.G. Kaiser. 1960. Alfalfa to replace sweetclover for dryland green manure crop rotations in Pacific Northwest. J. Soil Water Conserv. 15:257-263.

Silver, W.S., and R.W.F. Hardy. 1976. Newer developments in biological dinitrogen fixation of possible relevance to forage production, p. 1-34 In: Biological $\mathbf{N}$ fixation in forage-livestock systems. ASA Spec. Pub. 28. Madison, Wis.

Smith, W.K., and H.J. Gorz. 1965. Sweetclover improvement. Adv. Agron. 17:163-231.

Steel, R.G.D., and J.H. Torrie. 1980. Principles and procedures of statistics. McGraw-Hill, N.Y.

Ta, T.C., and M.A. Faris. 1987a. Effects of alfalfa proportions and clipping frequencies on timothy-alfalfa mixtures. I. Competition and yield advantages. Agron. J. 79:817-820.

Ta, T.C., and M.A. Faris. 1987b. Effects of alfalfa proportions and clipping frequencies on timothy-alfalfa mixtures. II. Nitrogen fixation and transfer. Agron. J. 79:820-824,

Turkington, R.A., P.B. Cavers, and E. Rempel. 1976. The biology of Canadian weeds. Can. J. Plant Sci. 58:523-537.

Ward, K.J., B. Klepper, R.W. Rickman, and R.R. Allmaras. 1978. Quantitative estimation of living wheat-root lengths in soil cores. Agron. J. 70:675-677. 